\title{
Fibroblast Growth Factor-2 Expression Is Altered in Lambs With Increased Pulmonary Blood Flow and Pulmonary Hypertension
}

\author{
STEPHEN WEDGWOOD, JENNIFER M. DEVOL, ALBERT GROBE, EILEEN BENAVIDEZ, ANTHONY AZAKIE, \\ JEFFREY R. FINEMAN, AND STEPHEN M. BLACK

\begin{abstract}
Department of Pediatrics [S.W., J.M.D.], Northwestern University, Chicago, Illinois 60611; Department of Biomedical and and Pediatrics [J.R.F.], University of California-San Francisco, San Francisco, California 94143
\end{abstract} \\ Pharmaceutical Sciences [A.G., E.B., S.M.B.], University of Montana, Missoula, Montana 59802; Departments of Surgery [A.A.]
}

\begin{abstract}
A lamb model of pulmonary hypertension, developed by inserting an aortopulmonary vascular graft (shunt), displays vascular remodeling and increased pulmonary blood flow characteristic of children with congenital heart disease. The purpose of this study was to determine whether expression of fibroblast growth factor-2 (FGF-2), a smooth muscle cell mitogen, is altered in shunt lambs. FGF-2 mRNA and protein levels were increased in lung tissue extracts from shunt lambs at $4 \mathrm{wk}$ of age relative to age-matched controls $(p<0.05)$. FGF-2 protein levels were also increased in the pulmonary arteries and serum of shunt lambs $(p<0.05)$. Pulmonary arterial smooth muscle cells (PASMC) and endothelial cells (PAEC) were isolated from 4 wk-old lambs and subjected to cyclic stretch and laminar shear stress to mimic increased pulmonary blood flow. Stretch and shear increased FGF-2 promoter activity, and intracellular and extracellular FGF-2 protein levels in both cell types $(p<0.05)$. Exogenous FGF-2 stimulated PASMC proliferation at levels detected in the extracellular medium of sheared cells $(p<0.05)$. Elevated FGF-2 signaling by PASMC and PAEC exposed to increased pulmonary blood flow may play a role in the pulmonary vascular remodeling associated with the shunt model of pulmonary hypertension secondary to congenital heart disease. (Pediatr Res 61: 32-36, 2007)
\end{abstract}

$\mathrm{C}$ HD with increased pulmonary blood flow is often associated with the development of pulmonary hypertension (1). After birth, as pulmonary vascular resistance normally decreases, the presence of a systemic to pulmonary communication generates an increase in pulmonary blood flow. This abnormal postnatal hemodynamic state results in progressive structural and functional abnormalities of the pulmonary vascular bed $(2,3)$. Our animal model of pulmonary hypertension, developed by inserting an aortopulmonary vascular graft in the late-gestational fetal lamb (4-6), may help elucidate the mechanisms involved. Postnatally, these shunt lambs have increased pulmonary blood flow and pressure (4). In addition, they display vascular remodeling typical of pulmonary hypertension secondary to CHD, characterized by increased medial wall thickness of the small pulmonary arteries and abnormal extension of muscle to peripheral pulmonary arteries $(1,4,7)$.

Received June 20, 2006; accepted August 17, 2006.

Correspondence: Stephen Wedgwood, Ph.D., Ward 12-189, 303 E. Chicago Ave., Chicago, IL 60611; e-mail: s-wedgwood@ northwestern.edu

Supported, in part, by grant $0330292 \mathrm{~N}$ from the American Heart Association National Office (SW) and grants HL60190 (SMB), HL67841 (SMB), HL072123 (SMB), HL070061 (SMB), and HL61284 (JRF) from the National Institutes of Health.

DOI: 10.1203/01.pdr.0000250013.77008.28
Recent studies have demonstrated that shunt lambs display abnormal signaling by several growth factors mitogenic for vascular smooth muscle, including ET-1 (6), transforming growth factor $\beta$-1 (TGF $\beta$-1) (8), and vascular endothelial growth factor (VEGF) (9). Another potential contributor to vascular remodeling is FGF-2. FGF-2 displays mitogenic effects in the early proliferation of $\operatorname{SMC}(10,11)$ and in neointimal thickening (12) following vascular injury. Furthermore, a progressive increase in FGF-2 protein within the smooth muscle layer of pulmonary arteries was demonstrated in a rat model of monocrotaline-induced pulmonary hypertension (13). In addition, elevated FGF-2 protein levels were detected in the urine and plasma of patients with pulmonary arterial hypertension, suggesting the involvement of FGF-2 in the SMC proliferation characteristic of this disease (14).

Vascular cells within arterial walls are subjected to biomechanical forces, including cyclic stretch generated by pulsatile blood flow. EC are also subjected to shear stress due to blood flow, and fluid dynamic models of intact blood vessels suggest that SMC also experience shear stress as a result of interstitial flow (15). Cyclic stretch increased FGF-2 mRNA in PASMC (16) and shear stress increased the release of FGF-2 from aortic SMC (17) and aortic EC (18). Since these biomechanical forces are increased in shunt pulmonary arteries due to elevated pulmonary blood flow, we hypothesized that similar to monocrotaline-induced and adult pulmonary hypertension, increased FGF-2 signaling may be associated with pulmonary vascular remodeling in shunt lambs. Thus, the purpose of this study was to monitor FGF-2 expression in shunt lambs, to determine the effects of cyclic stretch and shear stress on FGF-2 expression in PASMC and PAEC, and to determine the effects of exogenous FGF-2 on PASMC proliferation.

\section{MATERIALS AND METHODS}

Surgical preparation and care. Twenty mixed-breed Western pregnant ewes $(137-141 \mathrm{~d}$ gestation, term $=145 \mathrm{~d})$ were operated on under sterile conditions to insert an 8.0-mm Gore-tex vascular graft (2 mm length; W.L. Gore, Milpitas, CA) between the ascending aorta and main pulmonary artery of the fetus as previously described (4). Unoperated twin fetuses served as controls, because we have previously shown that unoperated and sham-

Abbreviations: CHD, congenital heart disease; EC, endothelial cells; ET-1, endothelin-1; ET $_{\mathbf{A}}$, endothelin A receptor; FGF-2, fibroblast growth factor-2; PAEC, pulmonary arterial endothelial cells; PASMC, pulmonary arterial smooth muscle cells; SMC, smooth muscle cells 
operated control lambs have similar physiology and morphology (4). Lambs were delivered spontaneously, and at $4 \mathrm{wk}$ of age were killed by an intravenous injection of pentobarbital sodium (Euthanasia CII; Central City Medical, Union City, CA) followed by bilateral thoracotomy. All procedures and protocols were approved by the Committee on Animal Research of the University of California, San Francisco.

Tissue/RNA/protein preparation. The heart and lungs were removed en bloc. Two to three gram sections from each lobe of the lung and sections from third- to fifth-generation intralobar pulmonary arteries and veins, with inside diameters of 0.5-2.0 mm, were removed. These tissues were snap-frozen in liquid nitrogen and stored at $-80^{\circ} \mathrm{C}$ until used. RNA and protein were isolated from snap-frozen lung tissue and analyzed by RNAase protection and Western blotting as described below. Tissue was prepared for immunohistochemistry as previously described (9).

RNAase protection assay. Antisense single-stranded riboprobes were synthesized by in vitro transcription from a plasmid containing an ovine FGF-2 cDNA fragment, and RNAse protection assays were performed on total RNA prepared from peripheral lung tissue as previously described $(5,19)$. Also included was a probe for $18 \mathrm{~S}$ to serve as a control for the amount of input total RNA and the recovery of protected probe fragments. In all experiments, sufficient counts were added such that the FGF-2 and $18 \mathrm{~S}$ riboprobes were always in molar excess.

Western blot analysis. Twenty micrograms of protein extracts were analyzed by Western blot analysis as previously described $(5,19)$. Membranes were incubated at room temperature with polyclonal antiserum raised against FGF-2 (sc-79, 1:200, Santa Cruz Biochemicals, Santa Cruz, CA) then incubated with a goat anti-rabbit IgG-horseradish peroxidase conjugate. After washing, chemiluminescence was used to detect the protein bands.

Immunohistochemistry. Lung tissue samples (snap frozen and stored at $-80^{\circ} \mathrm{C}$ ) were embedded in Tissue-Tek O.C.T Compound (Sakura Finetek USA Inc., Torrance, CA), cryosectioned at $5 \mu \mathrm{m}$, and stored at $-80^{\circ} \mathrm{C}$ until needed. Immunohistochemistry was performed using a 1:200 dilution of the anti-FGF-2 antibody (ab8880, Abcam Inc., Cambridge, MA) as described previously (9). Slides were imaged using an Olympus IX51 (Leeds Precision Instruments, Inc., Minneapolis, MN) and quantified using the Image Pro Plus software (MediaCybernetics, Silver Spring, MD)

Serum FGF-2 quantification. Systemic arterial blood was prepared as described previously (20). FGF-2 protein levels in serum samples were determined using a quantitative sandwich enzyme immunoassay technique (Quantikine, R \& D Systems, Minneapolis, MN). The OD of each well was read at $450 \mathrm{~nm}$, with wavelength correction at $540 \mathrm{~nm}$, using a Multiscan MCC/340 microplate reader (Labsystem, Helsinki, Finland).

Cell culture. Primary cultures of PASMC from 4-wk old sheep that had not previously been surgically operated were isolated by the explant technique as described previously (21). Identity was confirmed as PASMC by immunostaining (>99\% positive) with antibodies against $\alpha$-smooth muscle actin, calponin, and caldesmon. This was taken as evidence that cultures were not contaminated with fibroblasts or with endothelial cells. Primary cultures of PAEC were isolated as described previously (22). Endothelial cell identity was confirmed by their typical cobblestone appearance, contact inhibition, specific uptake of DiI-Ac-LDL (Molecular Probes, Eugene, OR), and positive staining for von Willebrand factor (DAKO, Carpinteria, CA).

All cultures for subsequent experiments were maintained in Dulbecco's modified Eagle medium (DMEM) supplemented with 10\% FCS (Hyclone Laboratories, Logan, UT), antibiotics (MediaTech, Herndon, VA), and antimycotics (MediaTech) at $37^{\circ} \mathrm{C}$ in a humidified atmosphere with $5 \% \mathrm{CO}_{2}-$ 95\% air. Cells were used between passages 3 and 10 .

Promoter analysis. A plasmid containing human FGF-2 promoter DNA from -1800 to +314 bp (relative to the transcription start site) fused to a luciferase reporter gene was a gift from Dr. M. Stachowiak and Dr. J. Moffett. Cells were co-transfected at $70 \%$ confluence with $4 \mu \mathrm{g}$ of plasmid DNA and $0.1 \mu \mathrm{g}$ of Renilla luciferase internal control vector on a $10 \mathrm{~cm}^{2}$ tissue culture plate using Effectine (QIAGEN, Valencia, CA) according to the manufacturer's instructions. After 24-h cells were split onto 6-well plates, maintained in DMEM containing 1\% serum and $10 \mu \mathrm{g} / \mathrm{mL}$ heparin, and left static or subjected to cyclic strain or laminar shear stress for 8-24 h as described below. Luciferase activity of $20 \mu \mathrm{L}$ protein extracts was determined using the Dual-Luciferase Reporter Assay System (Promega, Madison, WI) and a Femtomaster FB12 luminometer (Zylux, Oak Ridge, TN).

Cyclic stretch and fluid shear stress. Cells were maintained in DMEM containing $1 \%$ serum and $10 \mu \mathrm{g} / \mathrm{mL}$ heparin on 6-well BioFlex plates coated with collagen type I (FlexCell) for $24 \mathrm{~h}$, then subjected to biaxial cyclic stretch using the FlexCell 3000 Strain Unit. Plates were placed on a loading station and stretched by applying an oscillatory vacuum to the underside of the membranes. Cells were stretched at a frequency of $1 \mathrm{~Hz}$ with $20 \%$ amplitude for 8-24 h in accordance with a previous study (16).

Cells were maintained in DMEM containing $1 \%$ serum and $10 \mu \mathrm{g} / \mathrm{mL}$ heparin on 6-well tissue culture plates (Costar) for $24 \mathrm{~h}$ before initiating shear stress experiments. A cone-plate viscometer was designed and built such that it accepts 6-well plates (22). This allowed the PASMC and PAEC monolayer to be subjected to a radially constant fluid shear stress at laminar flow rates representing levels of shear stress within physiologic parameters. Typical physiologic shear stress in the major human arteries is in the range of 5-20 dynes $/ \mathrm{cm}^{2}$ (23). Thus, we imparted a shear stress of 20 dynes $/ \mathrm{cm}^{2}$ for $8-24$ $\mathrm{h}$ to mimic the upper limit of the physiologic range.

FGF-2 quantification by ELISA. Intracellular and extracellular FGF-2 protein levels were determined using a quantitative sandwich enzyme immunoassay technique (Quantikine). Cell extracts were adjusted for protein content then further diluted 1:100 before assay. To determine FGF-2 released, $100 \mu \mathrm{L}$ of undiluted medium was added per well of the precoated microplate. Samples and FGF-2 standards were assayed in duplicate for each assay according to the manufacturer's instructions. The OD of each well was read at $450 \mathrm{~nm}$, with wavelength correction at $540 \mathrm{~nm}$, using a Multiscan MCC/ 340 microplate reader (Labsystems).

Cell proliferation assays. Increases in PASMC number in response to exogenous FGF-2 were determined as described previously (21). Cells were seeded onto 96-well plates (Costar, Corning, NY) at approximately $25 \%$ confluence, allowed to adhere for at least $18 \mathrm{~h}$, then synchronized by serum starvation for a further $24 \mathrm{~h}$. Cells were then treated with $0-100 \mathrm{ng} / \mathrm{mL}$ recombinant human FGF-2 (Invitrogen, Carlsbad, CA) in serum-free medium. After $72 \mathrm{~h}$, viable PASMC number was determined using the Cell Titer 96 $\mathrm{AQ}_{\text {ueous }}$ One Solution kit (Promega), Twenty microliters of reagent was added directly to cells in $100 \mu \mathrm{L}$ medium, and, following a 2-h incubation period at $37^{\circ} \mathrm{C}$, the absorbance at $492 \mathrm{~nm}$ was read using a Labsystems Multiskan EX plate reader (Fisher Scientific, Pittsburgh, PA).

Statistical analysis. Unless otherwise stated, values are expressed as mean \pm $\mathrm{SD}$. Comparisons between treatment groups were made by the unpaired $t$ test using the GB-STAT or GraphPad Prism version 4.00 for Windows (GraphPad Software, San Diego, CA) software programs. A $p<0.05$ was considered statistically significant.

\section{RESULTS}

Analysis of FGF-2 mRNA by RNAse protection assays showed increased expression in shunt lambs relative to agematched control animals (Fig. $1 A$ ). Densitometric analysis of lower exposure autoradiographs to those presented in Figure $1 \mathrm{~A}$ indicated an $80 \%$ increase in shunt FGF-2 mRNA normalized to $18 \mathrm{~S}$ relative to control animals (Fig. $1 \mathrm{~B}$ ).

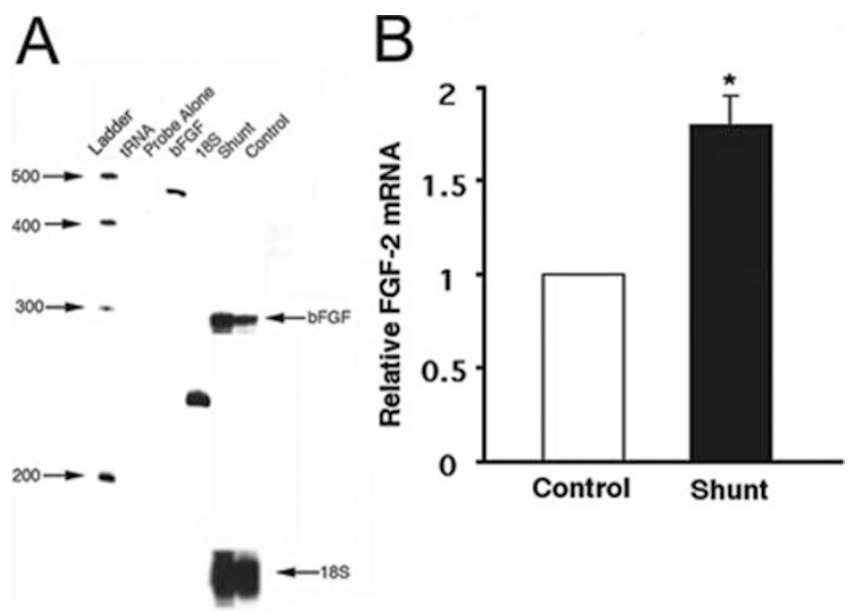

Figure 1. RNAase protection assays for FGF-2 (bFGF) on lung tissue from 4-wk-old lambs with increased (shunt) and normal (control) pulmonary blood flow and pressure. Representative RNAse protection assay $(A)$ showing that FGF-2 mRNA expression is increased in shunt lambs. A molecular weight ladder with sizes in nucleotides is presented in the left lane. "tRNA" is tRNA plus bFGF probe; "probe alone" is digested bFGF probe; "bFGF" is undigested bFGF probe; " $18 \mathrm{~S}$ " is undigested $18 \mathrm{~S}$ probe; "Shunt" is shunt RNA digested with bFGF and 18 S probes; "Control" is control RNA digested with bFGF and 18S probes. 18S RNA band indicates equal RNA loading. Densitometric values for relative FGF-2 mRNA (normalized to 18S RNA and to controls) from four control and four shunt lambs were determined $(B) . n=4$ shunt and 4 control animals. Values are means $\pm \mathrm{SD} . * p<0.05$, shunt $v s$ control. 


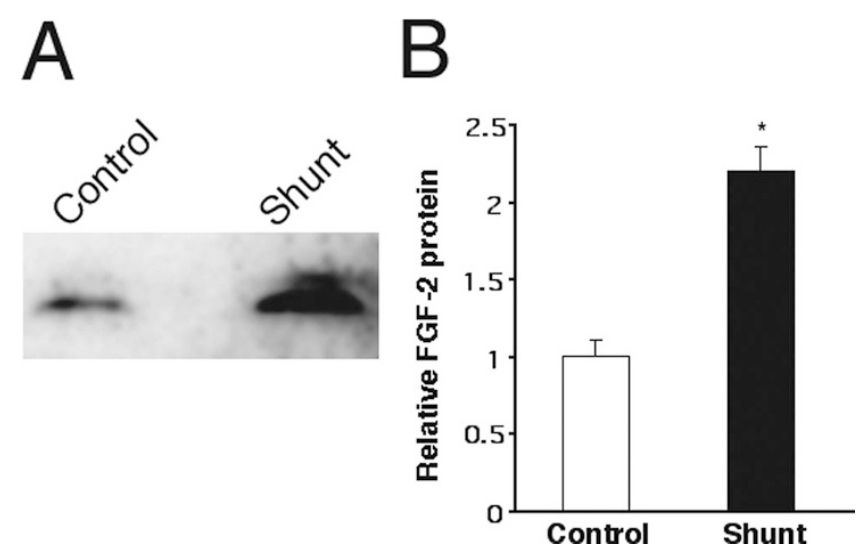

Figure 2. Western blot for FGF-2 from shunt and control lung tissue. Representative Western blot $(A)$ showing that FGF-2 protein is increased in shunt lambs relative to controls. Densitometric values for relative FGF-2 protein from four control and four shunt lambs were determined $(B) . n=4$ shunt and 4 control animals. Values are means $\pm \mathrm{SD} .{ }^{*} p<0.05$, shunt $v s$ control.

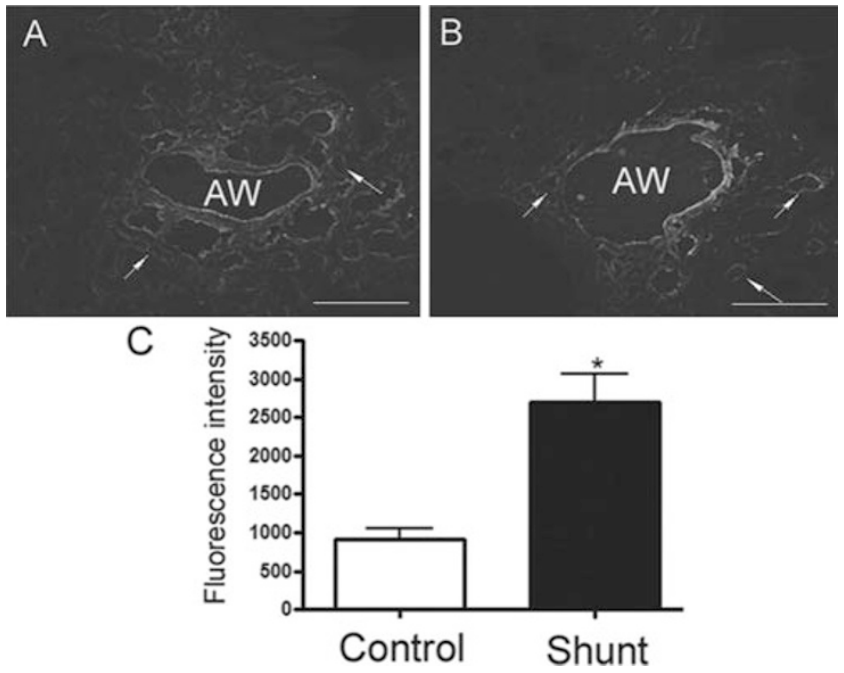

Figure 3. Immunohistochemistry to determine FGF-2 protein distribution and levels in lung tissue sections prepared from 4-wk-old shunt and control lambs. Representative images of control $(A)$ and shunt $(B)$ lung tissue stained with an anti-FGF-2 antibody. Calibration bars $=100 \mu \mathrm{m}$. Airways are indicated by "AW." Vessels are indicated by arrows. (C) Image Pro Plus software analysis was used to quantify FGF-2 protein in vessels. Shunts: $n=$ 7 animals, 70 vessels; controls: $n=3$ animals, 27 vessels. Values are mean \pm SD. $* p<0.05$ shunt $v s$ control.

The increase in FGF-2 mRNA was consistent with a significant increase in FGF-2 protein in lung tissue extracts from shunt animals as detected by Western blotting (120\% higher than controls, Fig. 2, $A$ and $B$ ).

The localization of FGF-2 protein expression in shunt and control lambs was evaluated by immunohistochemistry using peripheral lung tissue sections. FGF-2 staining was evident in all animals, with strong expression in the vessels (Fig. 3, $A$ and $B)$. Quantification of vessel-associated fluorescence demonstrated that FGF-2 protein was increased by $180 \%$ in shunt lamb vessels relative to controls (Fig. $3 \mathrm{C}$ ). Omission of either the primary or secondary antibody resulted in undetectable signals indicating lack of autofluorescence (data not shown).

ELISA indicated an increase in circulating FGF-2 protein in shunt animals, with serum concentrations more than 4-fold higher in shunts relative to controls (Fig. 4).

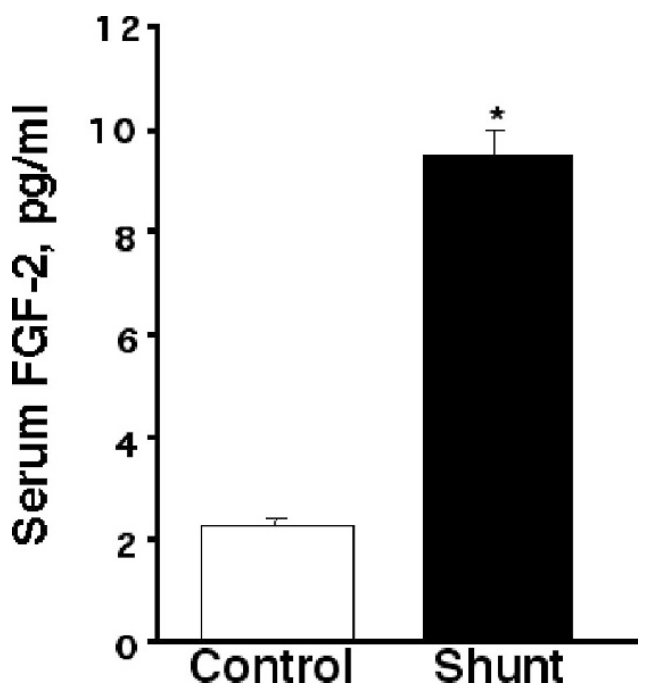

Figure 4. ELISA to quantify FGF-2 protein in serum from 4-wk-old control and shunt lambs. $n=4$ shunt and 4 control animals. Values are mean \pm SEM. $* p<0.05$ shunt $v s$ control.
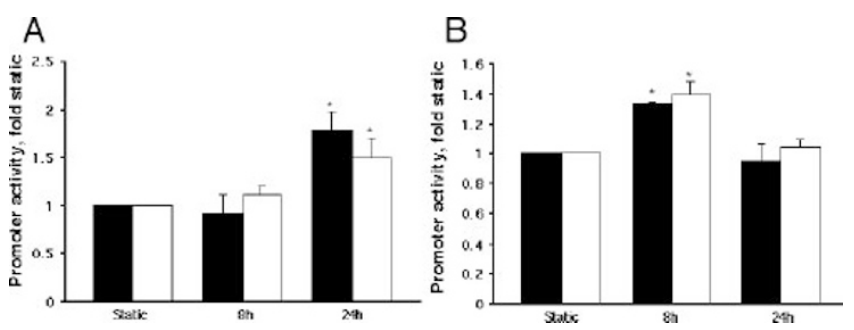

Figure 5. Luciferase assays to determine the activity of an 1800 bp FGF-2 promoter fragment in PASMC $(A)$ and PAEC $(B)$ exposed to $8 \mathrm{~h}$ and $24 \mathrm{~h}$ stretch $(\square)$ and shear $(\square) ; n=4$. Values are mean \pm SD. ${ }^{*} p<0.05 v s$ static cells.

PASMC and PAEC isolated from 4-wk-old lambs were subjected to $20 \%$ cyclic stretch at $1 \mathrm{~Hz}$ and $20 \mathrm{dyn} / \mathrm{cm}^{2}$ laminar shear stress to mimic physiologic levels of these biomechanical forces during pulsatile blood flow $(23,24)$. Using an 1800 bp FGF-2 promoter fragment fused to a luciferase reporter gene we first determined the time-dependent effects of biomechanical forces on FGF-2 promoter activity. In PASMC, $24 \mathrm{~h}$ of stretch and shear increased luciferase activity by $77 \%$ and $44 \%$, respectively, relative to static controls, with no significant change detectable after $8 \mathrm{~h}$ (Fig. $5 \mathrm{~A}$ ). In PAEC, promoter activity peaked after $8 \mathrm{~h}$ of stretch and shear (33\% and 39\%, respectively) before decreasing to basal levels by $24 \mathrm{~h}$ (Fig. $5 \mathrm{~B}$ ).

Intracellular FGF-2 protein levels were quantified from cells exposed to stretch and shear using an ELISA-based assay. Significant increases in intracellular FGF-2 protein were detected in PASMC after 8 and $24 \mathrm{~h}$ of stretch and shear (Fig. 6 A). At 24 h, stretch and shear increased levels by $43 \%$ and $178 \%$, respectively (Fig. 6 A). Intracellular FGF-2 levels were also elevated in PAEC, with values increasing by $59 \%$ and $175 \%$ after 24-h stretch and shear, respectively (Fig. 6 B).

FGF-2 released by cells exposed to stretch and shear was quantified by performing ELISA assays on the extracellular media. Eight and $24 \mathrm{~h}$ of shear significantly increased FGF-2 protein detected in the media surrounding PASMC by 15.9- and 13.6-fold, respectively, relative to static controls (Fig. 7 A). Conversely, 8-h stretch significantly increased 

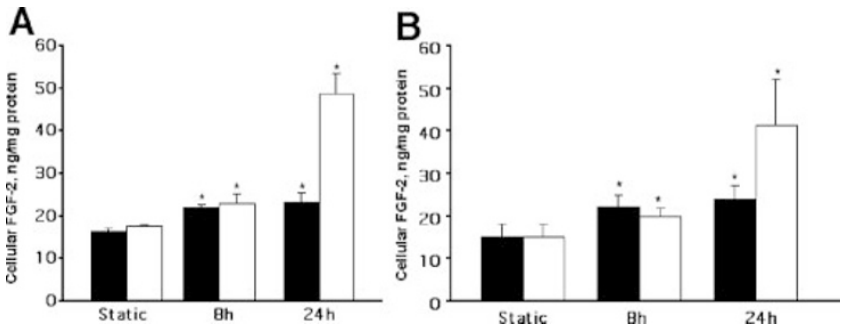

Figure 6. ELISA to determine FGF-2 protein content in cell extracts from PASMC $(A)$ and PAEC $(B)$ exposed to 8 and 24-h stretch ( $\square)$ and shear $(\square)$; $n=4$. Values are mean \pm SEM. $* p<0.05$ vs static cells.
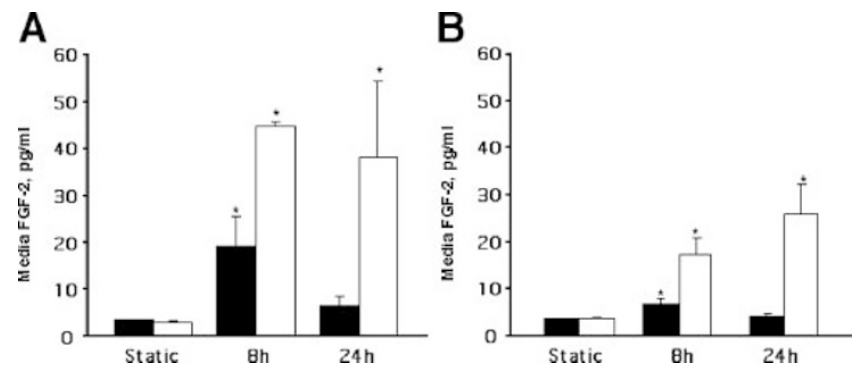

Figure 7. ELISA to determine FGF-2 protein content in extracellular media of PASMC $(A)$ and PAEC $(B)$ exposed to 8 and $24 \mathrm{~h}$ stretch $(\square)$ and shear $(\square) ; n=4$. Values are mean \pm SEM. $* p<0.05 v s$ static cells.

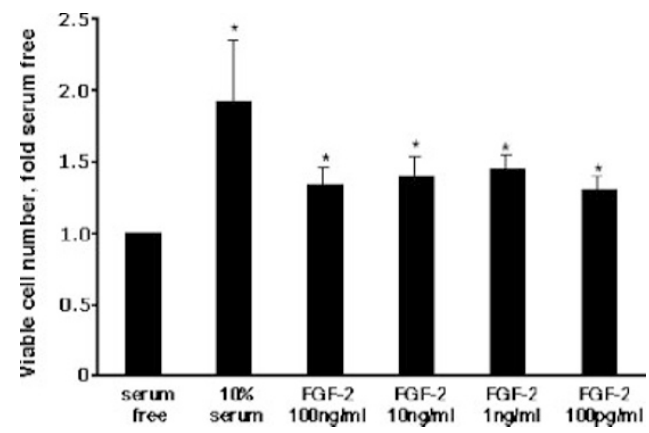

Figure 8. Viable cell assays to determine increases in PASMC number in response to exogenous FGF- $2 ; n=4$. Values are mean \pm SD. $* p<0.05$ vs serum free.

FGF-2 release by 5.9 -fold, before decreasing to a statistically insignificant level of 1.9-fold by $24 \mathrm{~h}$ (Fig. 7 A). In PAEC, shear increased FGF-2 released by 5.0 -fold and 7.5 -fold after $8 \mathrm{~h}$ and $24 \mathrm{~h}$, respectively (Fig. $7 \mathrm{~B}$ ), while stretch increased FGF-2 released by 1.9 -fold at $8 \mathrm{~h}$ before decreasing to basal levels by $24 \mathrm{~h}$ (Fig. 7 B).

We next determined the dose-dependent effects of exogenous FGF-2 on PASMC proliferation. At $72 \mathrm{~h}, 100 \mathrm{pg} / \mathrm{mL}$ FGF-2 increased viable PASMC number by $30 \%$ relative to serum-free medium (Fig. 8), while optimum growth medium containing $10 \%$ serum increased viable cell number by $92 \%$ (Fig. 8).

\section{DISCUSSION}

We have previously reported an underlying dysregulation of growth factor expression in 4-wk-old shunt lambs, including increases in ET-1 (6), TGF- $\beta 1$ (8), and VEGF (9) signaling. The present study identifies increased FGF-2 expression as another potential contributor to abnormal PASMC growth in the shunt model of pulmonary hypertension.

Our in vitro data suggest that biomechanical forces, resulting from increased pulmonary blood flow, may play a role in the up-regulation of FGF-2 expression within shunt pulmonary arteries. The increase in FGF-2 promoter activity in PASMC after $24 \mathrm{~h}$ of stretch is in agreement with a previous study demonstrating an $80 \%$ increase in FGF-2 mRNA in ovine PASMC exposed to $24 \mathrm{~h}$ of cyclic stretch (16). Our data further add to the existing knowledge of FGF-2 expression in SMC by demonstrating a role for shear stress in its regulation. Vascular SMC are normally exposed to shear stress due to interstitial flow driven by transmural pressure gradients (15), and to our knowledge this is the first study to provide evidence of increased FGF-2 transcription in vascular SMC in response to shear stress. The effects of biomechanical forces on endothelial FGF-2 expression appear to depend on the location of the cells within the vasculature. In bovine aortic EC, FGF-2 mRNA levels transiently increased after $6 \mathrm{~h}$ shear, while cyclic stretch had no effect (25). Conversely, increased FGF-2 mRNA was detected in human umbilical vein EC after $24 \mathrm{~h}$ of shear stress (26), while in vivo exposure of rat mesenteric small arteries to elevated flow failed to alter endothelial FGF-2 mRNA at any time over $7 \mathrm{~d}$ (27). Our data suggest that in the pulmonary circulation, stretch and shear both transiently increase FGF-2 promoter activity in PAEC.

The mechanisms that mediate the regulation of FGF-2 expression in PASMC and PAEC by biomechanical forces are currently unknown. We detected temporal differences in FGF-2 expression between PASMC and PAEC exposed to stretch and shear suggesting that cell-specific mechanisms including increased RNA and protein stability may be involved. In addition, stretch and shear may regulate FGF-2 expression in the same cell type via different pathways. For example, a shear stress-responsive element within the platelet-derived growth factor-B (PDGF-B) promoter was necessary for increased expression in bovine aortic EC exposed to shear (28), but not to stretch (29). Additional studies are therefore warranted to characterize the transcriptional, posttranscriptional, and posttranslational regulation of FGF-2 expression in PASMC and PAEC in response to stretch and shear.

Biomechanical forces may also exert indirect effects on FGF-2 expression and signaling in shunt lambs. TGF- $\beta 1$ expression was increased in 4-wk-old shunt animals relative to controls (8), which may be due in part to increased TGF- $\beta 1$ expression and release by PASMC exposed to stretch (30). Furthermore, TGF- $\beta 1$ expression was enhanced by increased flow and shear stress in vivo (31), and TGF- $\beta 1$ has been shown to up-regulate FGF-2 in vascular SMC (32). Together, these data suggest that induction of TGF- $\beta 1$ expression and release by biomechanical forces may stimulate FGF-2 expression in PASMC. Similar to patients with pulmonary arterial hypertension (14), our results show that 4-wk-old shunt lambs exhibit increased FGF-2 serum levels. This may be due, in part, to the stimulation of expression and release of FGF-2 from pulmonary vascular cells exposed to biomechanical forces. Several studies have demonstrated FGF-2 autoregulation (33), raising the possibility of sustained increases in FGF-2 expression in shunt pulmonary vascular cells via positive feedback mechanisms. While many other factors may be involved, these data illustrate the potentially complex regulation of FGF-2 expression in shunt lambs. 
Circulating FGF-2 may trigger PASMC growth by binding extracellular receptors, whereas increases in intracellular FGF-2 in PASMC exposed to stretch and shear can potentially stimulate cell proliferation by activating nuclear-localized receptors (33). FGF-2 may further contribute to pulmonary hypertension and vascular remodeling via its interaction with other growth factor signaling pathways. Neutralization of FGF-2 reduced VEGF release from vascular SMC (34), whereas FGF-2 was found to increase ET-1 subtype A receptor $\left(\mathrm{ET}_{\mathrm{A}}\right)$ expression in PASMC (35). $\mathrm{ET}_{\mathrm{A}}$ mRNA and protein levels were increased in shunt lambs (6), and ET-1 stimulated the proliferation of fetal PASMC via $\mathrm{ET}_{\mathrm{A}}$ receptor-mediated signaling (21). These data raise the possibility that FGF-2 may exert an additional indirect mitogenic effect on PASMC growth by up-regulating $\mathrm{ET}_{\mathrm{A}}$ receptor expression. In addition, this is likely to enhance the contribution made by ET-1-mediated vasoconstriction to pulmonary hypertension in shunt lambs. Further studies are needed to characterize the interaction between FGF-2 and ET-1 signaling pathways in shunt pulmonary arteries.

This study has focused on the role of biomechanical forces, although other factors may also contribute to abnormal FGF-2 expression in shunt lambs. Pulmonary arterial oxygen saturation was significantly increased in shunts due to the mixing of aortic and pulmonary arterial blood (4) $(63.3 \pm 11.4 \%$ shunts vs $42.0 \pm$ $5.8 \%$ controls, $p<0.05$; Dr. Jeffrey Fineman, unpublished observations). Although it is not yet known whether this increase in oxygen saturation is sufficient to stimulate FGF-2 expression in shunt lambs, levels of FGF-2 mRNA and protein were increased in the lungs of mice exposed to $80 \% \mathrm{O}_{2}$ for $4 \mathrm{~d}$ (36). Furthermore, exposure to $60 \% \mathrm{O}_{2}$ for $14 \mathrm{~d}$ increased ET-1-dependent PDGF-beta receptor expression in a newborn rat model of pulmonary hypertension with vascular remodeling (37). These data suggest that increased pulmonary arterial oxygen saturation may also contribute to abnormal FGF-2 and ET-1 signaling in shunt lambs.

Overall, the above data demonstrate the potential complex mechanisms that mediate abnormal FGF-2 signaling, and highlight the many roles that FGF-2 may play in contributing to pulmonary vascular remodeling in shunt lambs.

\section{REFERENCES}

1. Hoffman JI, Rudolph AM, Heymann MA 1981 Pulmonary vascular disease with congenital heart lesions: pathologic features and causes. Circulation 64:873-877

2. Nagumo K, Yamaki S, Takahashi T 2000 Extremely thickened media of small pulmonary arteries in fatal pulmonary hypertension with congenital heart disease-a morphometric and clinicopathological study. Jpn Circ J 64:909-914

3. Rabinovitch M, Bothwell T, Hayakawa BN, Williams WG, Trusler GA, Rowe RD, Olley PM, Cutz E 1986 Pulmonary artery endothelial abnormalities in patients with congenital heart defects and pulmonary hypertension. A correlation of light with scanning electron microscopy and transmission electron microscopy. Lab Invest 55:632-653

4. Reddy VM, Meyrick B, Wong J, Khoor A, Liddicoat JR, Hanley FL, Fineman JR 1995 In utero placement of aortopulmonary shunts. A model of postnatal pulmonary hypertension with increased pulmonary blood flow in lambs. Circulation 92:606-613

5. Black SM, Fineman JR, Steinhorn RH, Bristow J, Soifer SJ 1998 Increased endothelial NOS in lambs with increased pulmonary blood flow and pulmonary hypertension. Am J Physiol 275:H1643-H1651

6. Black SM, Bekker JM, Johengen MJ, Parry AJ, Soifer SJ, Fineman JR 2000 Altered regulation of the ET-1 cascade in lambs with increased pulmonary blood flow and pulmonary hypertension. Pediatr Res 47:97-106

7. Rabinovitch M, Haworth SG, Castaneda AR, Nadas AS, Reid LM 1978 Lung biopsy in congenital heart disease: a morphometric approach to pulmonary vascular disease. Circulation 58:1107-1122

8. Mata-Greenwood E, Meyrick B, Steinhorn RH, Fineman JR, Black SM 2003 Alterations in TGF-betal expression in lambs with increased pulmonary blood flow and pulmonary hypertension. Am J Physiol Lung Cell Mol Physiol 285:L209-L221

9. Mata-Greenwood E, Meyrick B, Soifer SJ, Fineman JR, Black SM 2003 Expression of VEGF and its receptors Flt-1 and Flk-1/KDR is altered in lambs with increased pulmonary blood flow and pulmonary hypertension. Am J Physiol Lung Cell Mol Physiol 285:L222-L231

10. Casscells W, Lappi DA, Olwin BB, Wai C, Siegman M, Speir EH, Sasse J, Baird A 1992 Elimination of smooth muscle cells in experimental restenosis: targeting of fibroblast growth factor receptors. Proc Natl Acad Sci U S A 89:7159-7163

11. Lindner V, Lappi DA, Baird A, Majack RA, Reidy MA 1991 Role of basic fibroblast growth factor in vascular lesion formation. Circ Res 68:106-113

12. Hanna AK, Fox JC, Neschis DG, Safford SD, Swain JL, Golden MA 1997 Antisense basic fibroblast growth factor gene transfer reduces neointimal thickening after arterial injury. J Vasc Surg 25:320-325

13. Arcot SS, Fagerland JA, Lipke DW, Gillespie MN, Olson JW 1995 Basic fibroblast growth factor alterations during development of monocrotaline-induced pulmonary hypertension in rats. Growth Factors 12:121-130

14. Benisty JI, McLaughlin VV, Landzberg MJ, Rich JD, Newburger JW, Rich S, Folkman J 2004 Elevated fibroblast growth factor levels in patients with pulmonary arterial hypertension. Chest 126:1255-1261

15. Wang DM, Tarbell JM 1995 Modeling interstitial flow in an artery wall allows estimation of wall shear stress on smooth muscle cells. J Biomech Eng 117:358-363

16. Quinn TP, Schlueter M, Soifer SJ, Gutierrez JA 2002 Cyclic mechanical stretch induces VEGF and FGF-2 expression in pulmonary vascular smooth muscle cells. Am J Physiol Lung Cell Mol Physiol 282:L897-L903

17. Rhoads DN, Eskin SG, McIntire LV 2000 Fluid flow releases fibroblast growth factor-2 from human aortic smooth muscle cells. Arterioscler Thromb Vasc Biol 20:416-421

18. Gloe T, Sohn H, Meininger G, Pohl U 2002 Shear stress-induced release of basic fibroblast growth factor from endothelial cells is mediated by matrix interaction via integrin alpha(v)beta3. J Biol Chem 277:23453-23458

19. Black SM, Johengen MJ, Ma ZD, Bristow J, Soifer SJ 1997 Ventilation and oxygenation induce endothelial nitric oxide synthase gene expression in the lungs of fetal lambs. J Clin Invest 100:1448-1458

20. McMullan DM, Bekker JM, Johengen MJ, Hendricks-Munoz K, Gerrets R, Black SM, Fineman JR 2001 Inhaled nitric oxide-induced rebound pulmonary hypertension: role for endothelin-1. Am J Physiol Heart Circ Physiol 280:H777-H785

21. Wedgwood S, Dettman RW, Black SM 2001 ET-1 stimulates pulmonary arteria smooth muscle cell proliferation via induction of reactive oxygen species. Am J Physiol Lung Cell Mol Physiol 281:L1058-L1067

22. Wedgwood S, Mitchell CJ, Fineman JR, Black SM 2003 Developmental differences in the shear stress-induced expression of endothelial NO synthase: changing role of AP-1. Am J Physiol Lung Cell Mol Physiol 284:L650-L662

23. Dewey CF Jr, Bussolari SR, Gimbrone MA Davies PF 1981 The dynamic response of vascular endothelial cells to fluid shear stress. J Biomech Eng 103:177-185

24. Dobrin PB 1978 Mechanical properties of arteries. Physiol Rev 58:397-460

25. Malek AM, Gibbons GH, Dzau VJ, Izumo S 1993 Fluid shear stress differentially modulates expression of genes encoding basic fibroblast growth factor and plateletderived growth factor B chain in vascular endothelium. J Clin Invest 92:2013-2021

26. Passerini AG, Milsted A, Rittgers SE 2003 Shear stress magnitude and directionality modulate growth factor gene expression in preconditioned vascular endothelial cells. J Vasc Surg 37:182-190

27. Tulis DA, Prewitt RL 1998 Medial and endothelial platelet-derived growth factor A chain expression is regulated by in vivo exposure to elevated flow. J Vasc Res 35:413-420

28. Resnick N, Collins T, Atkinson W, Bonthron DT, Dewey CF Jr, Gimbrone MA Jr 1993 Platelet-derived growth factor B chain promoter contains a cis-acting fluid shear-stress-responsive element. Proc Natl Acad Sci U S A 90:4591-4595.

29. Sumpio BE, Du W, Galagher G, Wang X, Khachigian LM, Collins T, Gimbrone MA Jr, Resnick N 1998 Regulation of PDGF-B in endothelial cells exposed to cyclic strain. Arterioscler Thromb Vasc Biol 18:349-355

30. Mata-Greenwood E, Grobe A, Kumar S, Noskina Y, Black SM 2005 Cyclic stretch increases VEGF expression in pulmonary arterial smooth muscle cells via TGFbeta1 and reactive oxygen species: a requirement for $\mathrm{NAD}(\mathrm{P}) \mathrm{H}$ oxidase. Am J Physiol Lung Cell Mol Physiol 289:L288-L298

31. Song RH, Kocharyan HK, Fortunato JE, Glagov S, Bassiouny HS 2000 Increased flow and shear stress enhance in vivo transforming growth factor-betal after experimental arterial injury. Arterioscler Thromb Vasc Biol 20:923-930

32. Brogi E, Wu T, Namiki A, Isner JM 1994 Indirect angiogenic cytokines upregulate VEGF and bFGF gene expression in vascular smooth muscle cells, whereas hypoxia upregulates VEGF expression only. Circulation 90:649-652

33. Stachowiak MK, Fang X, Myers JM, Dunham SM, Berezney R, Maher PA, Stachowiak EK 2003 Integrative nuclear FGFR1 signaling (INFS) as a part of a universal "feed-forward-and-gate" signaling module that controls cell growth and differentiation. J Cell Biochem 90:662-691

34. Bassus S, Herkert O, Kronemann N, Gorlach A, Bremerich D, Kirchmaier CM, Busse R, Schini-Kerth VB 2001 Thrombin causes vascular endothelial growth factor expression in vascular smooth muscle cells: role of reactive oxygen species. Arterioscler Thromb Vasc Biol 21:1550-1555

35. Li P, Oparil S, Sun JZ, Thompson JA, Chen YF 2003 Fibroblast growth factor mediates hypoxia-induced endothelin-a receptor expression in lung artery smooth muscle cells. J Appl Physiol 95:643-651

36. Powers MR, Planck SR, Berger J, Wall MA, Rosenbaum JT 1994 Increased expression of basic fibroblast growth factor in hyperoxic-injured mouse lung. J Cell Biochem 56:536-543

37. Jankov RP, Kantores C, Belcastro R, Yi S, Ridsdale RA, Post M, Tanswell AK 2005 A model for platelet-derived growth factor beta-receptor in a newborn rat model of endothelin-mediated pulmonary vascular remodeling. Am J Physiol Lung Cell Mol Physiol 288:L1162-L1170 